Article

\title{
The Status of Saying: Witness against Rhetoric in Levinas's Philosophy
}

\author{
Tomohiro Inukai
}

Graduate School of Arts and Letters, Meiji University, 1-1, Kanda-surugadai, Chiyoda, Tokyo 101-8301, Japan; dogg.tomohiro@gmail.com

Received: 25 October 2018; Accepted: 10 December 2018; Published: 12 December 2018

\begin{abstract}
In regard to rhetoric, Emmanuel Levinas stands against its violence. In spite of the rhetoric, he justifies the notion of discourse in Totality and Infinity in order to prove the possibility of the ethical relationship between the Same and the Other. In later works, he also criticizes the ontological language, which is used in the tradition of occidental philosophy. He explores a third way and proposes the notion of Saying, opposed to Said, as ethical language, witness in Otherwise than Being. However, there is a paradoxical structure of language. Although the Saying precedes the Said, the system of language and even the ontological language, it has to be reduced to this latter when it is expressed as philosophical form. The present study situates what is at stake in the criticism of rhetoric and ontological language by Levinas and examines the notion of witness as opposed to these forms of language. Witness is a concrete form of ethical language that consists in "for the other" of the ultimate passivity of the subjectivity. Therefore, the Saying is possible only as witness where the subject is exposed to "a calling into question" by the Other.
\end{abstract}

Keywords: Emmanuel Levinas; philosophy; rhetoric; discourse; witness; religion; Height of the Other; the relation between the Saying and the Said

\section{Introduction}

This article discusses the development of Emmanuel Levinas's philosophy of language. His philosophy of language gives a brief insight into the diverse limits between the following fields: philosophical language and the language used in everyday life; philosophical language and literature; and philosophical language and theological language, etc. ${ }^{1}$ These limits, which are discussed in this study, have a paradoxical and unsteady structure and, therefore it is not possible to reduce them to any one of the mentioned disciplines. The limits, in Levinas's terms, are "extraction from essence ${ }^{2 "}$ and "ex-ception of the 'other than being' 3 ", exception not eternal but incessant. In this structure there is a non-linear process of the philosophical language 4 . On one hand, the proximity of the 'Other', or the face-to-face relation between one and the other determines the possible forms of language, which precedes to all the 'Said'. On the other hand, the Saying (which is situated in this proximity)—opposite to the Said-has to be translated in the form of the Said as philosophy. In other words, the converting of

\footnotetext{
The figure of limits is inspired by François-David Sebbah, (Sebbah 2001).

(Levians [1974] 2011, p. 21) (Eng. Trans. p. 8.).

Ibid., p. 21 (Eng. Trans. p. 8).

Raoul Moati shows that the ethic (the Saying, or otherwise than being) justifies the justice (the Said, or Being) dealing with Levinas's philosophical method called emphasis. "[I]t permits to obtain the ethical signification which is independent of the ontology (Moati 2016, pp. 46-47)". Although the pure Saying is impossible, the Said is injustice without the Saying. Paul Ricoeur also characterized Levinas's philosophy as hyperbole (Ricoeur 1990). Richard A. Cohen compares Ricoeur's philosophy and Levinas's, and examines Ricoeur's understanding on the hyperbole in Levinas (Cohen 2002).
} 
the Saying to the Said has to be carried out in the frame of philosophy. Based on this logic the following questions shall be discussed: Is it possible that the Saying holds importance in the philosophy? If it is of significance, what does it mean? How do we understand and discuss transcendence in the field of philosophy ${ }^{5}$ ? We need to think about the 'religious' aspects or the meaning of religion ${ }^{6}$ in Levinas's philosophy because Levinas does not refuse to refer to the ethical relation between people as religion insofar as the ethical relation between the Same and the Other does not constitute the totality, and insofar as it defines God and not the reverse ${ }^{7}$. In later works, Levinas proposes a kind of language in which ethical relation is possible: witness, or glorification of the Height of the Infinite. In addition, we need think about the rhetoric in his philosophy. Although he criticizes rhetoric in general, he adopts a philosophical method called emphase (emphasis), which derives from rhetoric ${ }^{8}$. It is implied that he attempted to obtain his own language in order to discuss the transcendence of the religious and of the ethic.

First, this paper discusses the opposition between rhetoric ${ }^{9}$ and discourse in Totality and Infinity because Levinas situates the rhetoric as violence and attempts to preserve the discourse as the genuine relation to the Other. The rhetoric plays an important role as an opponent to elaborate the notion of discourse. Secondly, it will show that the notion of discourse has a relation with the dimension of the Height, in which the transcendence of the Other preserves its own singularity. Finally, the paper examines the status of the Saying in relation to witness.

\section{Restricted Rhetoric and Teaching}

In ancient Greek philosophy, certain philosophers like Socrates and Plato, criticized Sophists for teaching their students to use what they did not actually know to persuade auditors by presenting a semblance of truth. The purpose of rhetoric for them was the art of speaking eloquently and persuading people. Aristotle established rhetoric as an art of persuasion consisting of three sections: a theory of argumentation called invention (inventio), a theory of style called elocution (elocutio), and a theory of composition (compositio). Paul Ricoeur indicates that Aristotle's rhetoric is connected to philosophy by the theory of argumentation (dialectic) (Ricoeur [1975] 1997, pp. 13-14) ${ }^{10}$. However, some argue that contrary to ancient rhetoric, contemporary rhetoric is limited to the theory of elocution, or even to the theory of simile (Ibid., pp. 13-14). For "restricted rhetoric," the only task is a taxonomic classification of the figures of speech (Ibid., pp. 13-14).

Rhetoric in Levinas's philosophy seems to be similar to Plato's although he uses terms of judiciary: judgment, "judged in absentia", and apology. In Totality and Infinity, rhetoric is defined as an action corrupting and bribing the freedom of another person. Essentially, his understanding of rhetoric is comparable to the "restricted rhetoric" of argumentation that Plato criticized. Here is a passage that elaborates Levinas's opinion on rhetoric:

5 Magdalene Thomassen shows chronologically and systematically how much the question of God is important for Levinas' philosophy. Thomassen concludes that the originality of his philosophy is the "innovative way to think God and, at the same time, to rethink the humanity of the human (Thomassen 2017, p. 258)". In this book, these two ways are articulated in the three movements: exit (sortie), sociality and signifyingness (signifiance).

6 Richard Cohen places significance on the ethical religion and monotheism in Levinas's philosophy and points out their paradoxical structure (Cohen 2010, pp. 207-25).

(Levinas [1961] 2010, p. 30) (Eng. Trans. p. 40); (Levinas [1994] 1999, p. 114).

8 See note 2.

9 Claire Elise Katz claims that "the Scriptural references are in fact rhetorical, but not "simply rhetorical"; they do pedagogical work for Levinas that other literary devices cannot accomplish" (Katz 2005, p. 160). Susan Handelman points out the importance of the rhetoric in Levinas' philosophy, examining the relation of language theories between Levinas and Chaïm Perelman. "Insofar as language defined here as a relation to another, Levinas seems to propose an ultimately "rhetorical" theory of language. He reiterates throughout his work, however, the ancient philosophical contempt for rhetoric, which he views as the approach to the neighbor through ruse, a mode of sophistic manipulation and violence rather than search for truth. Yet Levinas' insistence of language as preeminently a call or command before it is an exchange of information is at bottom 'rhetorical' (Handelman 1991, pp. 236-37)".

10 Cf. (Barthes 1970; Genette 1970). 
Not every discourse is a relation with exteriority. It is not the interlocutor our master whom we most often approach in our conversations, but an object or an infant, or a man of the multitude, as Plato says. Our pedagogical or psychagogical discourse is rhetoric, taking the position of him who approaches his neighbor with ruse. And this is why the art of the sophist is a theme with reference to which the true conversation concerning truth, or philosophical discourse, is defined. Rhetoric, absent from no discourse, and which philosophical discourse seeks to overcome, resists discourse (or leads to it: pedagogy, demagogy, psychagogy). It approaches the other not to face him, but obliquely-not, to be sure, as a thing, since rhetoric remains conversation, and across all its artifices goes unto the Other, solicits his yes. But the specific nature of rhetoric (of propaganda, flattery, diplomacy, etc.) consists in corrupting this freedom ${ }^{11}$.

In this passage, Levinas considers both rhetoric and philosophic discourse as ways to approach the Other. However, rhetoric approaches the Other obliquely, corrupting the freedom of the Other, thus, it is violence and injustice. The veritable discourse that is not violence or injustice lies in facing the other in the discourse.

Opposing to the notion of rhetoric, he proposed teaching as a modality of veritable discourse in which one approaches the Other without making him or her a theme. In other words, when people talk about the other, people actually talk about and in the world. Even when people talk about someone, discourse does not reach the Other, for the Other transcends our faculty to make a thing an object of the theme. The negativity of this expression "not to reach the Other" suggests, rather than a defect of our faculty of comprehension, a positivity of the Other: in the veritable discourse "then this being is nowise an object, is outside of all emprise. This disengagement from all objectivity involves, positively, this being's presentation in the face, his expression, his language. The other qua other is the Other ${ }^{12 "}$.

Levinas examines the notion of discourse in Totality and Infinity in the terms of the formal relation in the language, not in the style of discourse and its content. It is the formal relation in language that shows the nature of irreducibility of the Other ${ }^{13}$. In fact, as Levinas says:

Better than comprehension, discourse relates with what remains essentially transcendent. For the moment we must attend to the formal work of language, which consists in presenting the transcendent; a more profound signification will emerge shortly. Language is a relation between separated terms. To the one the other can indeed present himself as a theme, but his presence is not reabsorbed in his status as a theme. The word that bears on the Other as a theme seems to contain the Other. But already it is said to the Other who, as interlocutor, has quit the theme that encompassed him, and upsurges inevitably behind the said. Words are said, be it only by the silence kept, whose weight acknowledges this evasion of the Other ${ }^{14}$.

In this passage, we could note that there is an origin of the notions of Saying and Said, which are developed in Otherwise than Being. The language consists of a relationship between separate beings in which one talks to the other. When one talks about the other, one makes him or her a theme of the speech, that is, the subject comprehends the other as an object. Although one could understand the meaning of what he says about the other, the alterity of the other is not reduced to the comprehension of the subject. In other words, it remains an excess of the comprehension. This is why the alterity quits the theme by "passing over ${ }^{15 " .}$

\footnotetext{
(Levinas [1961] 2010, p. 66) (Eng. Trans. p. 70).

(Levinas [1961] 2010, p. 67) (Eng. Trans. pp. 70-71).

(Levinas [1961] 2010, p. 65) (Eng. Trans. p. 68). He criticizes the formulations of Martin Buber and Gabriel Marcel, while pointing out their importance at the same time.

14 (Levinas [1961] 2010, p. 212) (Eng. Trans. p. 195).

15 (Levians [1974] 2011, p. 13) (Eng. Trans. p. 2).
} 
Speech (parole) also plays an important role in the philosophy of language; those who speak to the other person face to face can come to the assistance (porter secours) of their words. "The interpellated one is called upon to speak; his speech consists in 'coming to the assistance' of his word-in being present ${ }^{16 "}$. Coming to the assistance is a modality of the expression of the Other and enables the correction of words in the speech and the understanding of the other.

\section{Cartesian Order and Idea of Infinity}

In Totality and Infinity Levinas explains the Idea of Infinity, following the third meditation of Descartes. The idea of Infinity is, for him, the relation itself between the Same and the Other in which one thinks more than he does. This idea implies a rupture of the structure of intentionality. While intentionality supposes satisfaction of its lack and adequateness, in the idea of Infinity there is an excess of the ideatum, the non-adequateness of its object. However, this negativity does not mean a defect of the intentionality, rather the transcendence of the alterity of the Other. Levinas refers to this non-intentionality in the idea of Infinity as 'Desire', opposed to the 'Need' that lies in lack.

A desire without satisfaction which, precisely, understands the remoteness, the alterity, and the exteriority of the other. For Desire this alterity, non-adequate to the idea, has a meaning. It is understood as the alterity of the Other and of the Most-High. The very dimension of heights opened up by metaphysical Desire ${ }^{17}$.

Although the alterity of the other implies the non-adequateness of the idea that a subject possesses, it has a positive meaning, or the Height. The Height encompasses the transcendence of the Transcendent and the independence from the perception of a subject. It entails a remoteness and an exteriority of the other for the subject. Since the Height is not an object of consciousness, it would be meaningless if the consciousness were considered only as the thematization. It is rather a condition of the consciousness in which one can judge truth or falsity. Levinas refers to the dimension of the Height as the 'Cartesian order'.

In order to preserve the transcendence of the Height, Levinas avoids making his philosophy a theology which treats God as a being and an object of consciousness. In this sense, his philosophy is atheism. "Atheism conditions a veritable relationship with a true God kath'auto. (...) The atheism of the metaphysician means, positively, that our relation with the Metaphysical is an ethical behavior and not theology, not a thematization ${ }^{18}$. What is the metaphysical relation with the Height? In this case, Desire is connected to the majesty of the Transcendent. He cites the last passage of the third meditation of Descartes in which the relation with the Infinite is irreducible to the comprehension of the Infinite, yet irreducible to mysticism ${ }^{19}$. For Levinas, "this paragraph appears to be not a stylistic ornament or a prudent hommage to religion, but the expression of this transformation of the idea of infinity conveyed by knowledge into Majesty approached as a face ${ }^{20 "}$. In later works, especially, Otherwise than Being he revisits the issue of the majesty which will be discussed later. For now, as contrasted with maieutic of Socrates, this relation is concretely understood.

The Cartesian order is opposed to the Socratic order, where one can gain knowledge by him or herself even with the aid of a maieutic, that is, one remains in the interiority of the Same; the master

\footnotetext{
(Levinas [1961] 2010, p. 65) (Eng. Trans. p. 69).

(Levinas [1961] 2010, p. 23) (Eng. Trans. p. 34).

(Levinas [1961] 2010, pp. 75-76) (Eng. Trans. pp. 77-78).

9 "... it seems to me right to linger for a while on the contemplation of this all-perfect God, to ponder at leisure His marvelous attributes, to intuit, to admire, to adore, the incomparable beauty of this inexhaustible light, so far at least as the powers of my mind may permit, dazzled as they are by what they are endeavoring to see. For just as by faith we believe that the supreme felicity of the life to come consists in the contemplation of Divine majesty, so do we now experience that a similar meditation, though one so much less perfect, can enable us to enjoy the highest contentment of which we are capable in this present life". Ed. Tannery, T. VII, p. 52 (Eng. Trans. Norman Kemp Smith (Descartes 1958), Philosophical Writing, New York, p. 211).

20 (Levinas [1961] 2010, p. 233) (Eng. Trans. p. 212).
} 
only leads his student to an answer which the student has forgotten. In the Cartesian order, the master, as the Other teaches something unknown which a student cannot know on his or her own. What does the master teach? What is the new thing for the student? Levinas says that what the master teaches is the expression of the Other in itself ${ }^{21}$. This expression of the Other in itself involves, first of all, the Goodness of the Other and the transcendence of the Other to a frame of understanding, or the comprehension of the student. This is a concrete situation in which the Idea of Infinity is produced. In the following passage, Levinas explains the priority of the Cartesian order to the Socratic order and records his reason and purpose for Totality and Infinity.

Teaching is a discourse in which the master can bring to the student what the student does not yet know. It does not operate as maieutic, but continues the placing in me of the idea of infinity. The idea of infinity implies a soul capable of containing more than it can draw from itself. It designates an interior being that is capable of a relation with the exterior, and does not take its own interiority for the totality of being. This whole work seeks only to present the spiritual according to this Cartesian order, prior to the Socratic order. For the Socratic dialogue already presupposes beings who have decided for discourse, who consequently have accepted its rules, whereas teaching leads to the logical discourse without rhetoric, without flattery or seduction and hence without violence, and maintaining the interiority of him who welcomes ${ }^{22}$.

Levinas criticizes that Socratic dialogue relies on an assumption that people have already participated in discourse and follow the rules of the discourse. On the other hand, the Cartesian order makes room for teaching by a master, "without rhetoric, without flattery or seduction and hence without violence". It is notable that Levinas considers that flattery and the seduction is rhetoric as violence. For Levinas, the notion of violence should be separated from murder and war. Violence consists of corrupting the freedom of the other and tempting the other. In these terms, it becomes understandable why Levinas takes the power of the Other imposing on us for violence "beyond all violence $^{23 "}$. In a Talmudic reading, he emphasizes and criticizes more radically a rhetorical aspect of Greek wisdom. Levinas says,

it [Greek wisdom] is also the possibility of speaking through signs which are not universally understood and which, as signs of complicity, thus have the power to betray. Greek wisdom, inasmuch as it is enveloped by ambiguity in a certain language, is thus a weapon of ruse and domination. In philosophy, it is the fact that it is open to sophistry; in science, that it places itself in the service of strength and politics. There would exist in purely human wisdom the power to invert itself into lie and ideology ( ... ) Not because it [Greek wisdom] would be knowledge, but because, in purely human knowledge without Torah, in pure humanism, this deviation already slips towards rhetoric and all the betrayals against which Plato himself struggled. Perhaps the Talmudic style whose interpretation is causing us so much difficulty is also precisely this struggle with rhetoric ${ }^{24}$.

According to Levinas, as there is an ambiguity of signs to betray the understanding, "Greek wisdom is a weapon of ruse and domination". Without the Torah, pure humanism-philosophy and science-is exposed to a risk of falling down into rhetoric. In this sense, Talmudic reading stands out against rhetoric. In the same text, interpreting a verb in Hebrew hesitikha, he places importance on a meaning of "the act of persuading, of convincing, of seducing with an idea, of alluring ${ }^{25}$ ", which is

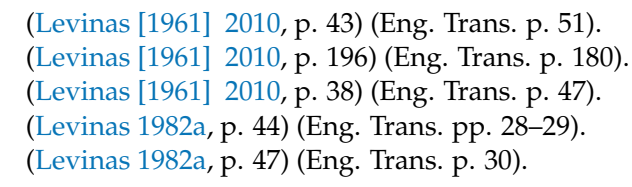


applied to God. "Here is God not teaching you by speaking to your reason, but teaching you (... ) by seducing you. Man allures and it ends badly, but God allures, God seduces too, as if God had his rhetoric. What is this divine allurement? Is there an allurement which does not deceive, a word which is not pure reason, yet which truly reveals? But is everything that is not reason before reason? Is there not an 'after' reason, a beyond reason? Divine allurement is the Torah ${ }^{26 \prime}$. God has a rhetoric without deceiving, as opposed to the rhetoric between people. It is the "rhetoric" of God that leads people to a beyond reason. What is the beyond reason? It is not "a simply crude opinion, or an element of faith, but a personal relation in the universal and truth $27 "$. Levinas, in this way, attempts to preserve the language as personal relation from the allurement and deception of language. It is true that Levinas does not use a word of Talmud in Totality and Infinity, but he is probably aware of the problem of the relation between teaching and rhetoric ${ }^{28}$.

\section{Witness: Paradox between Language and Height of Infinite}

In Otherwise than Being Levinas stops using some words used in Totality and Infinity and changes how to philosophize. For example, Joëlle Hansel remarks that Levinas no longer uses the term of teaching in the philosophical works after 1961, although it is seen in the Talmudic reading ${ }^{29}$. She explains why the teaching disappeared; the radicalization of the concept of subjectivity in Otherwise than Being and "God and Philosophy" ${ }^{30 " ~ m a d e ~ t h e ~ s u b j e c t i v i t y ~ e s s e n t i a l l y ~ p a s s i v e ~ t o ~ t h e ~}$ idea of infinity, so the subjectivity is affected by "the idea of infinity which no longer comes from the exteriority-from the teacher, but constitutes its structure itself ${ }^{31}$ ". The notion of teaching, as we saw in the previous section, was discovered as a concrete situation of the formal relation between the Same and the Other. Thus, the teacher was an aspect of the interlocutor. About this relation Levinas emphasized the separation between the Same and the Other, that is, the exteriority of the Other to the Same $^{32}$. Nevertheless, reinterpreting the idea of the infinity in 1974, he distinguishes the interlocutor from the infinity ${ }^{33}$ and leaves the latter to the dimension of the Height. In addition, he defines the subjectivity as "the other in the same ${ }^{34}$ ". The subjectivity is different from the consciousness, which "is always correlative with a theme, a present represented, a theme put before me, a being which is a phenomenon ${ }^{35 "}$. In this reinterpretation of the subjectivity, Levinas stresses a character of proximity between the Same and the Other. However, though proximity implies a short distance between two things, the separation and the exteriority of the Other are not denied. In this sense, the proximity is the other side of the separation. Indeed, he places the glory of the infinity out of the present, even all phenomenality: "The exteriority of the Infinite becomes somehow an inwardness in the sincerity of a witness borne ${ }^{36 "}$. The point is the meaning of "in" in the expression "the other in the same", or "the idea of the infinity in us ${ }^{37 "}$. For him, the idea of the infinity is in us, at the same time, incomprehensive. That implies there is a gap, or a disproportion between an idea and the infinity which exceeds this idea. Because of this excess, the infinity cannot be absorbed into the consciousness. Essentially, it cannot be present in a theme. The proximity is based on other order from the consciousness: signifyingness (signifiance). Therefore, the proximity calls for an appropriate language to describe it.

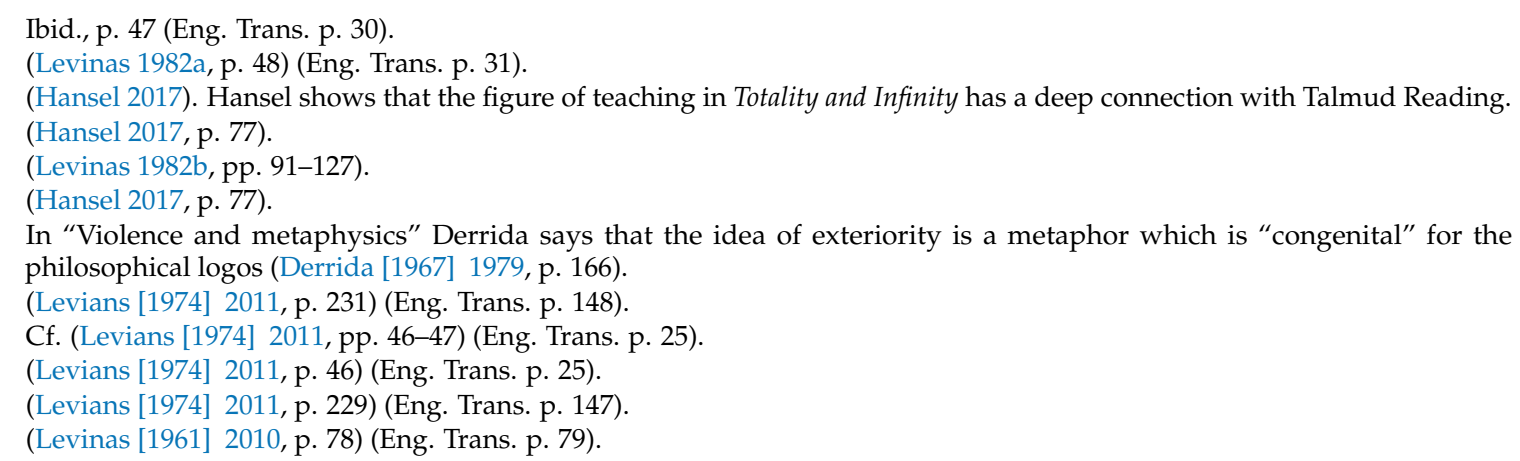


We can add the notion of discourse as another example of this development. Placed within a new framework of Saying and Said, it comes to be exposed to a risk. While the discourse was the veritable relation with the Other in Totality and Infinity, the way to present a concept is questioned in Otherwise than Being. It is philosophical language itself which is called into question. This type of language is also called ontological language which consists in questioning the essence of an object and it is categorized in the Said. The Saying, language pretending to say the transcendence of the Other, has to be said in the Said. Levinas is faced with a problem to investigate a possibility that the transcendence signifies otherwise than the Said. In order to solve this problem, he revisits the issue of the Height of infinity in Otherwise than Being. A form of language which is not absorbed in the Said is called witness.

However, it seems that the notion of witness, or glorification of the Infinite in Otherwise than Being, is close to rhetoric, as demonstrated by Catherine Chalier ${ }^{38}$. Comparing the witness in Levinas and the rhetoric in Aristotle, she points out how they are similar and different. Witness is apparently close to rhetoric in the terms of the truth of the argumentation. It does not necessarily lack the rationality, but it is different from demonstrative reasoning, for example, the syllogism. Since a witness gives only a point of view of what happened, it remains the verisimilitude. "The witness, thus, belongs to the genre of rhetoric: it is based on the persuasive force of the words and the discourses, based on the eloquence of who gives a witness, based on its proper capacity to cause the consent and the emotion ${ }^{39}$ ".

What philosophical meaning does Levinas discover in the witness? There are at least two meanings. At first, the expression of 'Here I am' means that the 'I' placed in the relation with the Other who comes to it in the perspective of proximity, not of knowledge, has a responsibility to the Other. Secondly, the relation with God who remains hidden in the pronoun of $I l$ ('It' in French) who always passes over is not reduced to an alternative being or not being of God.

In a text published in 1981, Levinas inquires into the essence of ordinary language ${ }^{40}$. Contrary to a tradition in which the Saying is excluded and in which its priority is lost (he mentions Plato, Hegel, Husserl in his early works, and Heidegger), although no Saying is detached from the Said, the Saying has an intrigue of sense, signifyness (signifiance) of approaching the other. The intrigue of sense affects the passivity of subjectivity and calls for the responsibility to the other in the proximity.

There is certainly no saying which is not Saying of a Said. However, does the Saying signify only the Said? Must not we bring out, from the Saying, an intrigue of sense which is not reduced to the thematization and exposition of a Said, [as to say] to the correlation where the Saying would make a being and Being [étant et être] appear by 'putting together' nouns and verbs in proposition, and by synchronizing them to present a structure? The Saying signifies otherwise than its function of apparition! Beyond the thematization of the Said and of the content that is exposed in the proposition, the apophansis signifies as a modality of the approach to the other. The proposition is proposed to the other person ${ }^{41}$.

The apophansis and proposition, which are also used in Otherwise than Being, belong to the Said insofar as they are understood in the sense of thematization: for this makes objects appear in the present, in the presence of a consciousness. It is remarkable that this explanation of the structure of the Saying in such a way is also inevitably done in the same way, thus, in the form of the Said. In Otherwise than Being, Levinas also states more explicitly the recurrence from the Saying to the Said. "The very discussion which we are at this moment elaborating about signification, diachrony and the transcendence of the approach beyond being, a discussion that means to be philosophy, is a

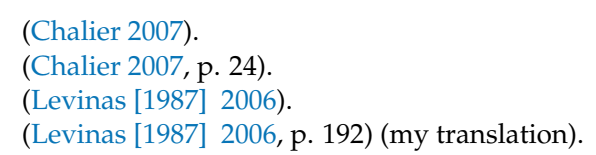


thematizing, a synchronizing of terms, a recourse to systematic language, a constant use of the verb being, a bringing back into the bosom of being all signification allegedly conceived beyond being 42 ".

After going back to the dimension of the Height of infinity, or the beyond being, from empirical situation, Levinas's philosophy now returns to the everyday life, properly speaking, and faces the "extraordinary everydayness 43 ". This movement is neither a simple return to the same place nor a one-time movement. While everyday life is composed of the consciousness in which people eat, sleep, work, calculate, represent something and talk with someone, in the extraordinary everydayness they certainly do the same things, but they would demand nothing in return, even forget their own death to save the other. For Levinas, these 'actions' do not mean the activity but the passivity of the subjectivity because the subject is subject to the infinity before his or her freedom. The passivity of the subjectivity seen in these 'actions', finally, is called "signification" and "one-for-the-other 44 " in Levinas's terms. What is the connection between this signification and the one-for-the-other? Concerning the one-for-the-other, Chalier points out that the etymology of the word of témoignage (witness in French) is from martyr in Greek ${ }^{45}$. In this sense, the witness is the glorification of the Height. Concerning the signification, Levinas says that the subject understood in the passivity "does not give signs, it becomes a sign, turns into an allegiance ${ }^{46 "}$. Generally, signification is a function of a sign; a sign (as the signifier) indicates other thing (as the signified) of itself, or the substitution between one and the other. In the Levinassian sense, signification is the subject as a sign, and, thus, the movement for the other without regarding of the self ${ }^{47}$.

\section{Conclusions}

We opened this paper by noting the paradoxical and unsteady structure of the figure of lines between various fields of language in order to reveal the development of the relation between the Saying and the Said. We first analyzed the notions of rhetoric and discourse in Totality and Infinity, and the analysis demonstrated the nature of rhetoric; it corrupts the freedom of the other as violence in the Socratic order. On the other hand, the priority of teaching as genuine discourse has a positive meaning of the transcendence of the Other, or Height in the Cartesian order. The teaching is the expression of the Other in itself, kath'auto.

In later works, Levinas changed the perspective of his philosophy rather than those notions adopted in Totality and Infinity. The analysis on the relation between the Saying and the Said permits his philosophy to relate with the Height of the Other. The Height is neither an object of the consciousness nor a being, but a value transcending it, the glory of the Infinite. However, the Height remains outside the way philosophy proposes a concept and puts a question on the essence, though it does not mean it is necessary to abandon the form of proposition. The only possibility left for philosophy is to find a room for witness in the form of proposition, in the approach to the Other; otherwise philosophy will remain rhetoric as injustice.

In conclusion, Levinas's philosophy primarily consists of finding the signification of the ethic as one-for-the-other ${ }^{48}$. He had to struggle with and overcome the rhetoric in his exploration because it infiltrates the everyday life. How did he discover the ethic? It is by incessantly drawing back from everyday life to its relation with the infinity that the one can find the extraordinary in this life.

Funding: This research received no external funding.

Conflicts of Interest: The author declares no conflict of interest.

\footnotetext{
(Levians [1974] 2011, p. 242) (Eng. Trans. p. 155).

(Levians [1974] 2011, p. 220) (Eng. Trans. p. 141).

(Levians [1974] 2011, p. 220) (Eng. Trans. p. 141).

(Chalier 2007, p. 25).

(Levians [1974] 2011, p. 83) (Eng. Trans. p. 49).

This is the authentic sense of substitution in Levinas's terminology.

After the investigation on the ethic, the possibility to think the political thing will be opened.
} 


\section{References}

Barthes, Roland. 1970. L'ancienne rhétorique. Communications 16: 172-223. [CrossRef]

Chalier, Catherine. 2007. Témoignage et théologie. Pardès 42: 17-30. [CrossRef]

Cohen, Richard A. 2002. Moral Selfhood: A Levinassian Response to Ricoeur on Levinas. In Ricoeur as Another: The Ethics of Subjectivity. Edited by Richard A. Cohen and James L. Marsh. Albany: State University of New York Press, pp. 127-60.

Cohen, Richard A. 2010. Levinassian Meditations. Ethics, Philosophy, and Religion. Pittsburgh: Duquesne University Press.

Derrida, Jaqcues. 1979. L'écriture et Différence. Paris: Seuil. First published 1967.

Descartes, René. 1958. Philosophical Writing. New York: Modern Library.

Genette, Gérard. 1970. La rhétorique restreinte. Communications 16: 158-71. [CrossRef]

Handelman, Susan. 1991. Fragments of Redemption: Jewish Thought and Literary Theory in Benjamin, Scholem, and Levinas. Bloomington and Indianapolis: Indiana University Press.

Hansel, Joëlle. 2017. Déformaliser la transcendance: La figure du maître dans Totalité et infini. In Totalité et inifni. Une CEuvre de Ruptures. Collectif sous la direction d'Éric Hoppenot, Michel Olivier et Joëlle Hansel. Paris: Manucius, pp. 57-74.

Katz, Claire Elise. 2005. Levinas-Between Philosophy and Rhetoric: The "Teaching" of Levinas's Scriptural References. Philosophy and Rhetoric 38: 159-71. [CrossRef]

Levinas, Emmanuel. 1982a. Au-delà du verset. Paris: Minuit, Translated by Gary D. Mole. As Beyond the Verse. Bloomington and Indianapolis: Indiana University Press.

Levinas, Emmanuel. 1982b. De dieu qui vient à l'idée. Paris: Vrin.

Levinas, Emmanuel. 1999. Transcendance et hauteur. In Liberté et Commandement. Paris: Livre de poche, pp. 59-117. First published 1994.

Levinas, Emmanuel. 2006. Hors Sujet. Paris: Livre de poche. First published 1987.

Levinas, Emmanuel. 2010. Totalité et Infini. Essai sur l'extériorité. Paris: Livre de poche, Translated by Alphonso Lingis. As Totality and Infinity. An Essay on Exteriority. Pittsburgh: Duquense University Press. First published 1961.

Levinas, Emmanuel. 2011. Autrement qu'être ou au-delà de l'essence. Paris: Livre de poche, Translated by Alphonso Lingis. As Otherwise than Being. Pittsburgh: Kluwer Academic Publisher. First published 1974.

Moati, Raoul. 2016. L'ontologie d'autrement qu'être. In Relire Autrement qu'être ou au-delà de l'essence d'Emmanuel Levinas. Edited by D. Cohen-Levinas et A. Schnell. Paris: Vrin.

Ricoeur, Paul. 1990. Soi-même comme un autre. Paris: Seuil, Translated by Kathleen Blamey. As Oneself as Another. Chicago: The University of Chicago.

Ricoeur, Paul. 1997. Métaphore Vive. Paris: Seuil, Translated by Robert Czerny, Kathleen McLaughlin, and John Costello. As The Rule of Metaphor. London: Routledge \& Kegan Paul. First published 1975.

Sebbah, François-David. 2001. L'épreuve de la limite. Derrida, Henry, Levinas et la phénoménologie. Paris: P. U. F. Thomassen, Magdalene. 2017. Traces de dieu dans la philsophie d'Emmanuel Levinas. Paris: Cerf.

(C) 2018 by the author. Licensee MDPI, Basel, Switzerland. This article is an open access article distributed under the terms and conditions of the Creative Commons Attribution (CC BY) license (http:// creativecommons.org/licenses/by/4.0/). 